\section{Priss 0., Burdina I., Kiurchev 5., Verkholantseva V., Stepanenko D.}

\title{
EFFECT OF SEED SOWING PERIOD ON POLYPHENOLIC COMPOUNDS CONTENT IN BASIL (OCIMUM BASILICUM L.) UNDER GREENHOUSE CONDITIONS
}

Досліджено вплив різних строків висіву насіння п'яти сортів базиліку на накопичення поліфенольних речовин. Встановлено, що сорти з фіолетовим забарвленням листків накопичують поліфенолів більше порівняно з зеленими сортами на 51,2-66,6 \%. У зелених сортів Бадьорий, Рутан та Сяйво простежується підвищення рівня поліфенолів з кожним наступним зрізуванням зелені за лютневого та квітневого строку висіву насіння.

ключові слова: базилік, поліфенольні сполуки, строки висіву насіння, число зрізувань зелені.

\section{Introduction}

The climatic conditions of Ukraine cause seasonal production of vegetable products. Thus, the priority role in providing the population with fresh vegetables in the interseason period belongs to the vegetable growing in protected ground. Greenhouse production has several advantages over traditional cultivation [1,2]:

- higher green mass output per unit of area;

- high commodity quality;

- control of diseases and pests;

- temperature control, rational use of water and fertilizers.

Modern horticulture in Ukraine requires the constant development of production of valuable, rare, non-traditional for this climatic zone vegetable plants, in particular, spicy and aromatic [3]. The culture of sweet basil - one-year spice-aromatic herb from the family Laminaceae is wellfitting to these criteria [4]. It is well-spread in France, Hungary, Bulgaria, Germany, Italy, Israel, Egypt, Mexico, Indonesia and the United States [5, 6]. The attractiveness of this spice lies, first of all, in the diversity of flavours and the leaf colour. The range of basil use is very wide:

- fresh or dry flowers and leaves are used in food production for the manufacture of canned food, pickles, tomato sauces, in sausage and spice production;

- in medicine and cosmetology as a medicinal plant [7];

- in the landscape design, as a decorative culture $[8,9]$.

Basil contains a large amount of biologically active substances, which are represented by different classes, but polyphenolic compounds play one of the main roles. Their chemical structure includes a large number of hydroxyl groups, which neutralize free radicals, stop chain reactions, absorb atomic oxygen. Polyphenols are the main component of the overall antioxidant activity of spicy aromatic cultures, including those of basil. Studies show that the antioxidant properties of phenolic compounds are 4-5 times higher than the antioxidant potential of vitamins C and E [10]. Therefore, the study of the patterns of formation of the complex of polyphenolic compounds in plant products is important.

\section{The object of research and its technological audit}

The object of the research is the process of formation of the polyphenolic complex by basil plants.

The polyphenolic complex of basil is represented by a number of acids: caffeic, rosmarinic, caftaric, chicoric, which are accumulated in basil in high concentrations [11, 12] and have a significant effect on the antioxidant status of the plant [13-15]. The polyphenolic complex of purple basil type also includes a high level of anthocyanins [12] that are water-soluble phenolic compounds responsible for the red and purple coloration. As well as polyphenolic acids, anthocyanins have antioxidant properties. It is proved that consumption of plants rich in anthocyanins reduces the risk of neurodegenerative diseases [16].

However, the formation of polyphenolic compounds is affected by a number of biotic and abiotic factors, leading to variation in the level of polyphenols in a very wide range even for plants of the same cultivar.

\section{The aim and objectives of research}

The aim of the research is to determine the effect of the seed sowing period on the formation of the polyphenolic complex by plants.

Research objectives:

1. To determine the level of polyphenols accumulation in cultivars of basil with different colours of leaves.

2. To analyze the dynamics of formation of the complex of polyphenolic compounds depending on the seed sowing period in cultivars with different colours of leaves.

3. To reveal the patterns of formation of polyphenols at repeated cutting off of growing green mass.

\section{Research of existing solutions of the problem}

Active synthesis of polyphenolic compounds is a protective reaction of plants to various harmful exogenous influences [13-15]. Any biotic or abiotic stress (the effect of pathogenic fungi, bacteria, viruses, temperature fluctua- 
tions, mechanical damage, high light intensity, ultraviolet irradiation, imbalance of mineral components in the soil, drought, salinity, action of herbicides and salts of heavy metals) can lead to the intensification of polyphenolic compounds biosynthesis in various anatomical parts of the plant [16]. Also, the level of polyphenols varies depending on the agrotechnical elements of cultivation (cultivars, planting schemes, mineral nutrition, substrates, etc.) [11,17].

Basil with purple leaves accumulates more phenols in comparison with green-leaf cultivars [18]. For example, the authors of [19] noted that basil cultivars with purple leaves contained from 81.7 to $126.2 \mathrm{mg} / \mathrm{g}$ of dry weight of polyphenolic compounds while the green leaves cultivars from 35.6 to $62.9 \mathrm{mg} / \mathrm{g}$ of dry weight. This fact can be explained by the presence of anthocyanins in the pigment complex of purple basil. In other research, the level of polyphenols ranged from $3.16 \pm 0.62 \mathrm{mg} / \mathrm{g}$ in DarkGreen to $5.90 \pm 0.29 \mathrm{mg} / \mathrm{g}$ in RedOpal [20].

It is known that the level of polyphenolic compounds may vary depending on the number of cuttings. In studies of Italian scientists [21], the level of rosmarinic acid was greater in the case of the second cutting by $74.8 \%$ in comparison to the first cutting of green mass, and the level of caffeic and ferulic acids was increasing gradually till the third cutting. Such changes in the polyphenolic complex of basil are explained by the reaction of plants to high stress caused by cuttings.

In addition, there are data that confirm the dependence of the level of polyphenolic compounds of basil with purple leaves coloration on the plant's age. So, the level of polyphenols varied from $3.30 \mathrm{mg} / \mathrm{g}$ of dry weight in young plants to $20.08 \mathrm{mg} / \mathrm{g}$ of dry weight in aged ones [22].

The analysis of modern world scientific literature confirms the lack of research in this area, which determines the relevance and practicality of such research.

\section{Methods of research}

5.1. Plant materials, growing and harvesting conditions. The experiment was conducted under the greenhouse conditions in 2014-2016. The cultivars of basil, included in the State register of plant varieties suitable for dissemination in Ukraine were used in the research, namely:

- Bad'oryi (as control) and Rutan that have green leaf coloration;

- Filosof and Purpurova zoria with purple coloration;

- Siaivo with mainly green color with anthocyanin inclusions.

The determination of the optimal seed sowing period for basil included the following options of the study:

1 - sowing seeds in the 3rd decade of February;

2 - sowing seeds in the 2nd decade of March;

3 - sowing seeds in the 2nd decade of April.

Seeds were sown in boxes in rows with a row-spacing width of $5 \mathrm{~cm}$. The temperature during seed germination was maintained at $22-25^{\circ} \mathrm{C}$. Upon the formation of the first pair of leaves, the plants were transplanted into $6 \times 6 \mathrm{~cm}$ pots. The seedlings were planted after the formation of three pairs of leaves. The accounting area was $2 \mathrm{~m}^{2}$, the experiment was repeated five times. Five research plants were marked in each accounting area, followed by phenological observations and biometric measurements.
5.2. The method of determining the polyphenol content. The content of polyphenolic compounds was determined by the Folin-Denis reagent according to DSTU 4373:2005 [11].

The obtained data were mathematically computed using AgrostatNew (Ukraine) and Microsoft Excel software.

\section{Research results}

Seed sowing periods affected the growth of green mass after cutting. Sowing of seeds in March and April contributed to the rapid growth of the greenery and allowed making 5 cuttings of green mass in all cultivars of basil. After sowing the seeds in February, 5 cuttings of greens were successfully taken only for cultivars of purple color Filosof and Purpurova zoria. For the Bad'oryi cultivar, 4 cuttings were made, and only 3 were made for the Rutan and Siaivo cultivars, after which the greenery stopped growing, the plants stiffened and bloomed. Such increased resistance of purple basil to the stress conditions, namely the lack of light, an increase of temperature during the vegetation period can be explained by the presence of anthocyanins in the polyphenolic complex of plants. Anthocyanins accumulate and possess the highest antioxidant activity in cloudy, cool and extremely hot days [23].

At the time of the first cutting, that is at the beginning of the budding phase, the greatest amount of polyphenolic substances was accumulated by cultivars with purple leaves Filosof (average $-317.9 \mathrm{mg} \times 100 \mathrm{~g}^{-1}$ ) and Purpurova zoria (288.4 mg $\times 100 \mathrm{~g}^{-1}$ on average), which is significantly more than in the control cultivar Bad'oryi by $66.6 \%$ and $51.2 \%$, respectively. The polyphenolic complex of green cultivars Rutan and Siaivo was also more powerful than in the control. The level of polyphenols in these cultivars was in the range of $249.3-254.0 \mathrm{mg} \times 100 \mathrm{~g}^{-1}$. Two-factor analysis showed that there is no reliable difference between these cultivars (Table 1).

In our studies, the dynamics of polyphenols accumulation varied, depending on the number of cuttings and, especially, on the period of seed sowing. In the green cultivars (Bad'oryi, Rutan and Siaivo), an increase in the level of polyphenols with each subsequent cutting of greens during the February and April seed sowing periods can be observed. This fact indicates the lignification of vascular tissues, and hence the aging of the plant.

A slightly different trend can be observed in the Filosof and Purpurova zoria cultivars with purple leaf coloration. The difference between the cultivars is not reliable. In February, the highest level of polyphenols (369.8-385.2mg/100 g) was observed in the greens of the first cutting. This can be explained by the activation of the plant protective mechanism (accumulation of anthocyanins) in stress conditions, namely the low amount of light. For basil of these cultivars, the level of polyphenols decreased with further cuttings. For the April sowing period, there is an opposite tendency of phenolic compounds accumulation in these cultivars. Due to more favourable conditions at the initial growth stages, the content of polyphenolic compounds in the greens of the 1st-3rd cuttings was $233.3-257.0 \mathrm{mg} / 100 \mathrm{~g}$ in the Filosof cultivar and $173.2-188.6 \mathrm{mg} / 100 \mathrm{~g}$ in the Purpurova zoria cultivar. Further development of the plant took place under excessive air temperatures and high light intensity, which had caused premature aging of the plants, accumulation of lignins and accumulation of anthocyanins, as protection against excessive UV radiation at the time 
of the fourth and fifth cutting of greenery [24, 25]. The authors' studies show that high temperatures induce expression of genes, responsible for synthesis of flavonoids that prevent harmful effects of high temperatures [26]. This may also be due to the accumulation of polyphenols during aging of the plants [22].

Table 1

The content of phenolic compounds in basil, $\mathrm{mg} / 100 \mathrm{~g}$ (average over 2014-2016 years)

\begin{tabular}{|c|c|c|c|c|c|c|}
\hline \multirow{2}{*}{ Cultivar } & \multirow{2}{*}{ Sowing periods } & \multicolumn{5}{|c|}{ Cutting } \\
\hline & & I & II & III & IV & V \\
\hline \multirow{3}{*}{ Bad'oryi } & III dec. of February & 166.9 & 176.2 & 185.0 & 213.1 & - \\
\hline & II dec. of March & 237.0 & 241.2 & 221.4 & 215.2 & 216.7 \\
\hline & II dec. of April & 168.4 & 180.2 & 206.2 & 220.2 & 227.5 \\
\hline \multicolumn{2}{|c|}{ Average for cultivar } & 190.8 & 199.2 & 204.2 & 216.2 & - \\
\hline \multirow{3}{*}{ Butan } & III dec. of February & 276.7 & 300.7 & 335.7 & - & - \\
\hline & II dec. of March & 256.1 & 264.8 & 257.2 & 260.2 & 257.6 \\
\hline & II dec. of April & 215.2 & 223.6 & 253.7 & 267.1 & 278.7 \\
\hline \multicolumn{2}{|c|}{ Average for cultivar } & 249.3 & 263.0 & 282.2 & - & - \\
\hline \multirow{3}{*}{ Filosof } & III dec. of February & 385.2 & 370.7 & 345.4 & 338.3 & 314.2 \\
\hline & II dec. of March & 335.3 & 327.5 & 339.0 & 340.6 & 337.2 \\
\hline & II dec. of April & 233.3 & 232.9 & 257.0 & 359.5 & 380.8 \\
\hline \multicolumn{2}{|c|}{ Average for cultivar } & 317.9 & 310.4 & 313.8 & 346.1 & 344.1 \\
\hline \multirow{3}{*}{$\begin{array}{l}\text { Purpura- } \\
\text { va zoria }\end{array}$} & III dec. of February & 369.8 & 342.4 & 325.9 & 314.4 & 289.0 \\
\hline & II dec. of March & 322.1 & 303.5 & 315.2 & 312.9 & 311.0 \\
\hline & II dec. of April & 173.2 & 159.1 & 188.6 & 296.0 & 325.8 \\
\hline \multicolumn{2}{|c|}{ Average for cultivar } & 288.4 & 268.3 & 276.6 & 307.8 & 308.6 \\
\hline \multirow{3}{*}{ Siaivo } & III dec. of February & 215.3 & 237.1 & 315.4 & - & - \\
\hline & II dec. of March & 274.8 & 285.0 & 277.0 & 268.8 & 263.7 \\
\hline & II dec. of April & 271.8 & 277.6 & 299.7 & 307.9 & 313.1 \\
\hline \multicolumn{2}{|c|}{ Average for cultivar } & 254.0 & 266.6 & 297.4 & - & - \\
\hline \multirow{3}{*}{$\begin{array}{l}\text { Aver- } \\
\text { age for } \\
\text { sowing } \\
\text { terms }\end{array}$} & III dec. of February & 282,78 & 285.4 & 301.5 & - & - \\
\hline & II dec. of March & 285,07 & 284.4 & 282.0 & 279.5 & 277.2 \\
\hline & II dec. of April & 212,40 & 214.7 & 241.0 & 290.1 & 305.2 \\
\hline \multicolumn{2}{|c|}{$\mathrm{LSD}_{0.05}$ (for cultivars) } & 3 & 14.0 & .3 & - & - \\
\hline \multicolumn{2}{|c|}{ LSD $_{0.05}$ (for sowing periods) } & 7.6 & 7.5 & 2.6 & - & - \\
\hline
\end{tabular}

In case of sowing seeds in March, the level of polyphenols in all cultivars did not significantly change during the sequence of cuttings, indicating the stress decrease and optimal cultivation conditions.

\section{SWOT analysis of research results}

Strengths. Among the strengths of this research, it is necessary to highlight the results concerning the accumulation and change of the content of polyphenolic compounds in common basil of different cultivars depending on the period of seed sowing and crop harvesting. The obtained data make it possible to solve the problem of selecting the optimal periods of basil seed sowing in greenhouses, which would enable to obtain the greens with a stable high content of polyphenolic compounds.

Weaknesses. Seed sowing periods are only one of the factors that influence the accumulation of biologically ac- tive substances, including polyphenolic compounds, in the greens of common basil. The level of polyphenols in vegetables also varies greatly depending on various agricultural practices of cultivation (planting schemes, soil mix, mineral nutrition, etc.), as well as environmental conditions (light, humidity, temperature, etc.). It is therefore necessary to conduct research on basil in greenhouses, which requires additional costs.

Opportunities. Growing greens in greenhouses allows solving the problem of seasonality of consumption and range. Therefore, improvement of technologies of cultivation of green vegetables with stable quality and high content of valuable phytonutrients in greenhouses is promising.

Threats. The content of endogenous antioxidants, including polyphenols, in vegetables is rather unstable, annual variations of polyphenols are observed depending on the agro-climatic cultivation conditions.

\section{Conclusions}

1. It is found that when grown in greenhouses, the cultivars with purple coloration of leaves accumulate by 51.2-66.6 \% more polyphenols than green varieties.

2. It is shown that seed sowing periods significantly affect the level of polyphenols in leaves of basil. At early sowing time (the third decade of February), cultivars with purple coloration of leaves accumulate more polyphenols in comparison with those in the later periods of seed sowing.

3. It is found that in the cultivars of basil with the green colour of leaves, the content of polyphenolic substances increases with each subsequent cutting of greens in case of early and late periods of sowing. Average seed sowing periods (the second decade of March) facilitated the slightest variation in the content of polyphenols, regardless of the cutting of greens. The cultivars with purple coloration of leaves accumulated the highest level of polyphenols for the first cutting of the February seed sowing period and for the fourth and fifth cuttings of the greens of the April sowing period. When sowing seeds in March, the level of polyphenols in all the cultivars did not significantly change during cutting, indicating optimum cultivation conditions.

\section{References}

1. Liu, R. H. Dietary Bioactive Compounds and Their Health Implications [Text] / R. H. Liu // Journal of Food Science. 2013. - Vol. 78, No. s1. - P. A18-A25. doi:10.1111/17503841.12101

2. Motorna, R. V. Efficiency of growing vegetable production in the closed soil in the region [Text] / R. V. Motorna // Vestnik Agrarian Science of the Black Sea Region. - 2007. Vol. 3, No. 42. - P. 163-168.

3. Vasilenko, O. V. Justification of technological measures for growing cornflowers in the Right-bank Forest-steppe of Ukraine [Text]: PhD Thesis / O. V. Vasilenko. - Kyiv: National University of Bioresources and Nature Management, 2009.

4. Ulyanich, O. I. Green and Spice Vegetable Cultures [Text] O. I. Ulyanich. - Kyiv: DIA, 2004. - 168 p.

5. Golcz, A. Bazylia pospolita (Ocimum basilicum L.) [Text] A. Golcz. - Poznan: Wydawnictwo Uniwersytetu Przyrodniczego, 2008. - $106 \mathrm{p}$

6. Nurzynska-Wierdak, R. Ocimum basilicum L. - wartosciowa roslina przyprawowa, lecznicza i olejkodajna [Text] / R. Nurzynska-Wierdak // Annales Universitatis Mariae Curie-Skłodowska. Sectio EEE: Horticultura. - 2012. - Vol. 22, No. 1. - P. 20-30.

7. Nurzynska-Wierdak, R. Bazylia pospolita (Ocimum basilicum L.), w: Uprawazioł [Text] / R. Nurzynska-Wierdak; ed. by B. Kołodziej. Pwril: Poznan, 2010 
8. Makri, O. Ocimumsp. (Basil): Botany, Cultivation, Pharmaceutical Properties, and Biotechnology [Text] / O. Makri, S. Kintzios // Journal of Herbs, Spices\&Medicinal Plants. 2008. - Vol. 13, No. 3. - P. 123-150. doi:10.1300/j044v13n03 10

9. Niederwieser, J. G. Guide to hydroponic vegetable production [Text] / J. G. Niederwieser. - Ed. 2. - Pretoria, Roodeplaat: Agricultural Research Council, Vegetable and Ornamental Plant Institute, 2001. - $140 \mathrm{p}$

10. Lapin, A. A. Antioxidant properties of balsams based on plant raw materials [Text] / A. A. Lapin // 5th (Jubilee) International Conference «Phytotherapy and New Technologies 21st century». - 2004. - P. 334-347.

11. Javanmardi, J. Chemical Characterization of Basil (Ocimum basilicumL.) Found in Local Accessions and Used in Traditional Medicines in Iran [Text] / J. Javanmardi, A. Khalighi, A. Kashi, H. P. Bais, J. M. Vivanco // Journal of Agricultural and Food Chemistry. - 2002. - Vol. 50, No. 21. - P. 5878-5883. doi:10.1021/jf020487q

12. Kwee, E. M. Variations in phenolic composition and antioxidant properties among 15 basil (Ocimum basilicum L.) cultivars [Text] / E. M. Kwee, E. D. Niemeyer // Food Chemistry. 2011. - Vol. 128, No. 4. - P. 1044-1050. doi:10.1016/j.foodchem.2011.04.011

13. Surveswaran, S. Systematic evaluation of natural phenolic antioxidants from 133 Indian medicinal plants [Text] / S. Surveswaran, Y. Cai, H. Corke, M. Sun // Food Chemistry. - 2007. - Vol. 102, No. 3. - P. 938-953. doi:10.1016/j.foodchem.2006.06.033

14. Wojdylo, A. Antioxidant activity and phenolic compounds in 32 selected herbs [Text] / A. Wojdylo, J. Oszmianski, R. Czemerys // Food Chemistry. - 2007. - Vol. 105, No. 3. - P. 940-949 doi:10.1016/j.foodchem.2007.04.038

15. Shan, B. Antioxidant Capacity of 26 Spice Extracts and Characterization of Their Phenolic Constituents [Text] / B. Shan, Y. Z. Cai, M. Sun, H. Corke // Journal of Agricultural and Food Chemistry. - 2005. - Vol. 53, No. 20. - P. 7749-7759. doi:10.1021/jf051513y

16. Gao, X. Habitual intake of dietary flavonoids and risk of Parkinson disease [Text] / X. Gao, A. Cassidy, M. A. Schwarzschild, E. B. Rimm, A. Ascherio // Neurology. - 2012. - Vol. 78, No. 15. - P. 1138-1145. doi:10.1212/wnl.0b013e31824f7fc4

17. Burdina, I. Effect of the Substrate Composition on Yield and Quality of Basil (Ocimum basilicum L.) [Text] / I. Burdina, O. Priss // Journal of Horticultural Research. - 2016. - Vol. 24, No. 2. - P. 109-118. doi:10.1515/johr-2016-0027

18. Brewer, M. S. Natural Antioxidants: Sources, Compounds, Mechanisms of Action, and Potential Applications [Text] M. S. Brewer // Comprehensive Reviews in Food Science and Food Safety. - 2011. - Vol. 10, No. 4. - P. 221-247. doi:10.1111/j.1541-4337.2011.00156.x

19. Juliani, H. R. Antioxidant activity of basil. Trends in new crops and new uses [Text] / H. R. Juliani, J. E. Simon; ed. by J. Janick, A. Whipkey - Alexandria, VA: ASHS Press, 2002 - P. 575-579.

20. Baratova, S. Impact of biofortification, variety and cutting on chosen qualitative characteristic of basil (Ocimum basilicum L.) [Text] / S. Baratova, I. Mezeyova, A. Hegedusova, A. Andrejiova // Acta fytotechnica et zootechnica. - 2015. Vol. 18, No. 3. - P. 71-75. doi:10.15414/afz.2015.18.03.71-75

21. Carlo, N. Influence of cut number on qualitative traits in different cultivars of sweet basil [Text] / N. Carlo, S. Silvia, B. Stefano, S. Paolo // Industrial Crops and Products. - 2013. - Vol. 44. P. 465-472. doi:10.1016/j.indcrop.2012.10.009

22. McCance, K. R. Influence of plant maturity on anthocyanin concentrations, phenolic composition, and antioxidant properties of 3 purple basil (Ocimum basilicum L.) cultivars [Text] /
K. R. McCance, P. M. Flanigan, M. M. Quick, E. D. Niemeyer // Journal of Food Composition and Analysis. - 2016. - Vol. 53. P. 30-39. doi:10.1016/j.jfca.2016.08.009

23. Proestos, C. RP-HPLC Analysis of the Phenolic Compounds of Plant Extracts. Investigation of Their Antioxidant Capacity and Antimicrobial Activity [Text] / C. Proestos, N. Chorianopoulos, G.-J. E. Nychas, M. Komaitis // Journal of Agricultural and Food Chemistry. - 2005. - Vol. 53, No. 4. - P. 1190-1195 doi:10.1021/jf040083t

24. Andersen, O. M. Flavonoids: Chemistry, Biochemistry and Applications [Text] / O. M. Andersen, K. R. Markham. - CRC Press, 2005. - 1256 p.

25. Parr, A. J., Phenols in the plant and in man. The potential for possible nutritional enhancement of the diet by modifying the phenols content or profile [Text] / A. J. Parr, G. P. Bolwell // Journal of the Science of Food and Agriculture. 2000. - Vol. 80, No. 7. - P. 985-1012. doi:10.1002/(sici)10970010(20000515)80:7<985::aid-jsfa572>3.3.co;2-z

26. Oren-Shamir, M. Temperature effects on the leaf pigmentation of Cotinus coggygria «Royal Purple» [Text] / M. Oren-Shamir, A. Levi-Nissim // Journal of Horticultural Science. - 1997. Vol. 72, No. 3. - P. 425-432. doi:10.1080/14620316.1997.11515530

\section{ИССЛЕДОВАНИЕ СОДЕРЖАНИЯ ПОЛИФЕНОЛЬНЫХ ВЕЩЕСТВ В БАЗИЛИКЕ (OCIMUM BASILICUM L.) В ЗАВИСИМОСТИ ОT СРОКОВ ПОСЕВА СЕМЯН В ТЕЛЛИЦАХ}

Исследовано влияние различных сроков посева семян пяти сортов базилика на накопление полифенольных веществ. Установлено, что сорта с фиолетовой окраской листьев накапливают полифенолов больше по сравнению с зелеными сортами на 51,2-66,6\%. У сортов с зелеными листьями (Бадёрый, Рутан и Сяйво) прослеживается повышение уровня полифенолов с каждым последующим срезанием зелени при февральском и апрельском сроках посева семян.

Ключевые слова: базилик, полифенольные соединения, сроки посева семян, число срезок зелени.

Priss Olesia, Doctor of Technical Sciences, Associate Professor Department of Technology of Processing and Storage of Agricultural Products, Tavria State Agrotechnological University, Melitopol, Ukraine, e-mail: olesyapriss@gmail.com, ORCID: http://orcid.org/ 0000-0002-6395-4202

Burdina Irina, Postgraduate Student, Department of Plant Growing, Tavria State Agrotechnological University, Melitopol, Ukraine, e-mail: irina.plehun@gmail.com, ORCID: http://orcid.org/00000002-5991-0186

Kiurchev Sergey, PhD, Professor, Head of the Department of Technology of Construction Materials, Tavria State Agrotechnological University, Melitopol, Ukraine, e-mail.dec.tgatu@ukr.net, ORCID: http://orcid.org/0000-0001-6512-8118

Verkholantseva Valentyna, PhD, Senior Lecturer, Department of Processing and Food Production Equipment named after professor F. Yalpachik, Tavria State Agrotechnological University, Melitopol, Ukraine, e-mail: wer.valentina@gmail.com,ORCID: http://orcid.org/ 0000-0003-1961-2149

Stepanenko Dmytro, PhD, Associate Professor, Department of Ecology and Zoology, Melitopol State Pedagogical University named after Bohdan Khmelnytsky, Ukraine, ORCID: http://orcid.org/00000002-6757-9382 